\title{
Different Nitrate and Ammonium Ratios Affect Growth and Physiological Characteristics of Camellia oleifera Abel. Seedlings
}

\author{
Rui Wang ${ }^{1,2,3}$, Longsheng Chen ${ }^{2,3}$, Jianjun Chen ${ }^{4}$, Yongzhong Chen ${ }^{2,3, *}$, Zhen Zhang ${ }^{2,3}$, \\ Xiangnan Wang ${ }^{2,3}$, Yinghe Peng ${ }^{2,3}$, Shaofeng Peng ${ }^{2,3}$, Anliang $\mathrm{Li}^{2,3}$ and Xiangying Wei ${ }^{4,5}$ \\ 1 Central South University of Forestry and Technology, Changsha 410004, China; wangrui102@163.com \\ 2 Hunan Academy of Forestry, Changsha 410004, China; clongsheng@163.com (L.C.); \\ csuftzz0526@163.com (Z.Z.); wangxiangnan04@yahoo.com.cn (X.W.); Pyinghe@163.com (Y.P.); \\ pengshaofengcsfu@sina.com (S.P.); lianliang181117@163.com (A.L.) \\ 3 National Engineering Research Center for Oil-tea Camellia, Changsha 410004, China \\ 4 Department of Environmental Horticulture and Mid-Florida Research and Education Center, Institute of \\ Food and Agricultural Science, University of Florida, Apopka, FL 32703, USA; jjchen@ufl.edu (J.C.); \\ weixiangying@ufl.edu (X.W.) \\ 5 College of Life Science, Fujian Agriculture and Forestry University, Fuzhou 350002, China \\ * Correspondence: chenyongzhong06@163.com; Tel.: +86-731-8565-7615
}

Received: 31 October 2018; Accepted: 17 December 2018; Published: 19 December 2018

\begin{abstract}
Camellia oleifera Abel., is an important woody plant, and its fruit contains high-quality edible oil. Production of $C$. oleifera has significantly expanded over the last 20 years in China. Due to the lack of appropriate information on nutrient management, its production has encountered low yield and low oil quality problems. As nitrogen $(\mathrm{N})$ is an essential nutrient and the most abundant in C. oleifera tissues, the present study investigated effects of different ratios of nitrate $\left(\mathrm{NO}_{3}{ }^{-}\right)$and ammonium $\left(\mathrm{NH}_{4}{ }^{+}\right)$on the growth of a cultivar Xianglin 27 at the seedling stage. Uniform seedlings were grown in a soil-based substrate in containers and fertigated with solutions composed of six ratios of $\mathrm{NO}_{3}{ }^{-}$ and $\mathrm{NH}_{4}{ }^{+}$, respectively for five months. Results showed that $C$. oleifera prefers both $\mathrm{NO}_{3}{ }^{-}$and $\mathrm{NH}_{4}{ }^{+}$ at a ratio of 1:1. Seedlings receiving this solution had the highest total $\mathrm{N}$ in leaves and total dry weight; elevated chrolophyll, soluble saccharide and protein contents as well as higher activities of peroxidase (POD), superoxide dismutase (SOD), nitrate reductase (NR), glutamine synthetase (GS), and glutamate synthase (GOGAT). Our study shows for the first time that $\mathrm{N}$ supply for producing C. oleifera should be an equal ratio of $\mathrm{NO}_{3}{ }^{-}$and $\mathrm{NH}_{4}{ }^{+}$.
\end{abstract}

Keywords: Nitrate and ammonium ratios; Camellia oleifera; nitrogen forms; tea oil trees

\section{Introduction}

Camellia oleifera Abel., a member of the Theaceae, is an oil tree species that has been exclusively cultivated in China due to its economic value [1]. Its fruit contains high-quality oil, commonly known as tea oil or camellia oil, which has $82 \%-84 \%$ unsaturated fatty acids, $68 \%-77 \%$ monounsaturated fatty acids, $67.7 \%-76.7 \%$ oleic acid, and $7 \%-14 \%$ polyunsaturated acid. The composition is similar to that of olive oil [2], hence it is called eastern olive oil [3]. Tea oil has also been widely used for cosmetic and medicinal purposes [4]. Furthermore, C. oleifera is tolerant to drought [5], and it can be produced in a wide range of mountainous areas in subtropical regions. With the increasing demand for self-sufficiency in cooking oil [3], the production of C. oleifera has significantly increased over the last 20 years. The current cultivated area for C. oleifera is more than three million ha in China $[6,7]$. 
The increasing production scope of tea oil trees, however, has encountered several problems including the lack of appropriate nutrient management programs, low crop yield, and variable oil quality [1,8]. Plant growth is highly dependent on mineral nutrient supply [9]. Among the essential nutrients, nitrogen $(\mathrm{N})$ is one of the most important macroelements that significantly affects plant growth, development, and product quality [10]. Analysis of distribution of nutrients in different organs of C. oleifera showed the most abundant element is $\mathrm{N}$ ranging from 3.2 to $12 \mathrm{~g} \mathrm{~kg}^{-1}$ compared to the next most abundant, potassium, ranging from 3 to $6 \mathrm{~g} \mathrm{~kg}^{-1}$ [8]. Thus, $\mathrm{N}$ is critically important for the growth of $C$. oleifera. Commercially, $\mathrm{N}$ is primarily applied in the form of nitrate $\left(\mathrm{NO}_{3}{ }^{-}\right)$, ammonium $\left(\mathrm{NH}_{4}{ }^{+}\right)$or urea $\left(\mathrm{CO}\left(\mathrm{NH}_{2}\right)_{2}\right)$. Applied urea will be converted to $\mathrm{NH}_{4}{ }^{+}$in soils then absorbed by plants, meaning that urea, although it is an organic $\mathrm{N}$ source, is considered the same as $\mathrm{NH}_{4}{ }^{+}$during the absorption process [11]. A large body of evidence suggests that both rates and forms of $\mathrm{N}$ fertilizers can affect plant growth and development [11-15]. In general, $\mathrm{NO}_{3}{ }^{-}$is considered to be the main $\mathrm{N}$ source for most crops [16], whereas plants adapted to acidic soils prefer $\mathrm{NH}_{4}{ }^{+}-\mathrm{N}$ and those adapted to high $\mathrm{pH}$ soils prefer $\mathrm{NO}_{3}{ }^{-}-\mathrm{N}[9]$.

Current fertilizer programs for C. oleifera production have focused on the formulation of $\mathrm{N}_{1} \mathrm{P}_{2} \mathrm{O}_{5}$, and $\mathrm{K}_{2} \mathrm{O}$ ratios and application rates $[17,18]$. Little attention has been given to the forms of $\mathrm{N}$ or the ratio of $\mathrm{N}$ forms on $\mathrm{C}$. oleifera growth. As $\mathrm{C}$. oleifera has adapted to red-acidic soils with $\mathrm{pH}$ around 5 [19], we hypothesized that $C$. oleifera would prefer $\mathrm{NH}_{4}{ }^{+}$over $\mathrm{NO}_{3}{ }^{-}$for its growth. The objective of this study was to test this hypothesis using uniform seedlings of $C$. oleifera as a model. Seedlings were fertilized with solutions comprised of six ratios of $\mathrm{NO}_{3}{ }^{-}$and $\mathrm{NH}_{4}{ }^{+}$for five months. Plant growth parameters and physiological characteristics were evaluated. Contrary to our hypothesis, C. oleifera prefers both $\mathrm{NO}_{3}{ }^{-}$and $\mathrm{NH}_{4}{ }^{+}$as $\mathrm{N}$ sources at a ratio of 1:1.

\section{Materials and Methods}

\subsection{Experiment Site}

The experiment was conducted at the experimental station of the National Engineering Research Center for Oil-tea Camellia, Changsha city, Hunan province, China $\left(113^{\circ} 01^{\prime}\right.$ E and $\left.28^{\circ} 06^{\prime} \mathrm{N}\right)$. The location has a subtropical monsoon climate with mild temperatures and distinct seasons. The annual lowest, highest, and average temperatures are $-12{ }^{\circ} \mathrm{C}, 40.6{ }^{\circ} \mathrm{C}$, and $17.3^{\circ} \mathrm{C}$, respectively. Annual average rainfall is approximately $1422 \mathrm{~mm}$, the frost-free period is 275 days, and the annual average relative humidity is $80 \%$.

\subsection{Plant Materials and Experimental Treatments}

Uniform seedlings of Camellia oleifera 'Xianglin 27' were grown from seeds in early March 2015 and transplanted to containers filled with a soil-based substrate (medium). The substrate was composed of yellow earth soil with sand, silt, and clay in a ratio of 2:3:1, perlite, and peat in a 3:1:1 ratio based on volume and had a $\mathrm{pH}$ of 5.8. The containers had a volume of $0.6 \mathrm{~L}$ with a height $12 \mathrm{~cm}$ and diameter of $8 \mathrm{~cm}$. Seedlings were grown in a greenhouse with a maximum photosynthetic radiation of $1000 \mu \mathrm{mol} \mathrm{m} \mathrm{m}^{-2} \mathrm{~s}^{-1}$, temperature ranging from 20 to $25^{\circ} \mathrm{C}$, and relative humidity of $50 \%-80 \%$.

To determine effects of different ratios of $\mathrm{NO}_{3}{ }^{-}$and $\mathrm{NH}_{4}{ }^{+}$on C. oleifera growth, six solutions were prepared weekly and used for fertigation (i.e., both fertilization and irrigation occurred at the same time) of seedlings. All solutions consisted of $261.39 \mathrm{mg} \cdot \mathrm{L}^{-1} \mathrm{~K}_{2} \mathrm{SO}_{4}, 136.09 \mathrm{mg} \cdot \mathrm{L}^{-1} \mathrm{KH}_{2} \mathrm{PO}_{4}$, $221.98 \mathrm{mg} \cdot \mathrm{L}^{-1} \mathrm{CaCl}_{2}, 120.37 \mathrm{mg} \cdot \mathrm{L}^{-1} \mathrm{MgSO}_{4}, 1.38 \mathrm{mg} \cdot \mathrm{L}^{-1} \mathrm{MnSO}_{4}, 2.86 \mathrm{mg} \cdot \mathrm{L}^{-1} \mathrm{H}_{3} \mathrm{BO}_{3}, 0.12 \mathrm{mg} \cdot \mathrm{L}^{-1}$ $\mathrm{ZnSO}_{4}, 0.05 \mathrm{mg} \cdot \mathrm{L}^{-1} \mathrm{CuSO}_{4}, 0.017 \mathrm{mg} \cdot \mathrm{L}^{-1} \mathrm{Na}_{2} \mathrm{MoO}_{4}, 10.94 \mathrm{mg} \cdot \mathrm{L}^{-1} \mathrm{FeSO}_{4}$, and $7 \mu \mathrm{mol} \mathrm{C}_{2} \mathrm{H}_{4} \mathrm{~N}_{4}$ (cyanoguanidine, a nitrification inhibitor) but varied in $\mathrm{NO}_{3}{ }^{-}$and $\mathrm{NH}_{4}{ }^{+}$ratios as indicated in Table 1 . $\mathrm{N}$ concentration in each solution was $8 \mathrm{mM}$ except the control treatment (T0) devoid of $\mathrm{N}$. 
Table 1. Six ratios of $\mathrm{NO}_{3}{ }^{-}$and $\mathrm{NH}_{4}{ }^{+}$used for studying effects of nitrogen forms on Camellia oleifera 'Xianglin 27' seedling growth.

\begin{tabular}{ccccc}
\hline Treatment & $\mathbf{N O}_{3}{ }^{-}: \mathbf{N H}_{\mathbf{4}}{ }^{+}$Ratio & Total $\mathbf{N}$ Concentration $(\mathbf{m M})$ & $\mathbf{N a N O}_{\mathbf{3}} \mathbf{( m M )}$ & $\mathbf{( N H}_{\mathbf{4}} \mathbf{~}_{\mathbf{2}} \mathbf{S O}_{\mathbf{4}} \mathbf{( \mathbf { m M } )}$ \\
\hline T0 & $0: 0$ & 0.0 & 0.0 & 0.0 \\
$\mathrm{~T} 1$ & $1: 0$ & 8.0 & 8.0 & 0.0 \\
$\mathrm{~T} 2$ & $7: 3$ & 8.0 & 5.6 & 1.2 \\
$\mathrm{~T} 3$ & $1: 1$ & 8.0 & 4.0 & 2.0 \\
$\mathrm{~T} 4$ & $3: 7$ & 8.0 & 2.4 & 2.8 \\
$\mathrm{~T} 5$ & $0: 1$ & 8.0 & 0.0 & 4.0 \\
\hline
\end{tabular}

After three months of growth, disease and pest free seedlings were selected and arranged in a randomized complete block design with three replications, and each replication had 10 seedlings per treatment. Seedlings were fertigated with six nutrient solutions, respectively. The fertigation started in mid-June 2015, at a rate of $150 \mathrm{~mL}$ per container weekly. If additional irrigation was needed, seedlings were irrigated with tap water. Besides fertigation, plants were well managed by pulling any weeds by hand.

\subsection{Seedling Growth Measurements}

Canopy heights of seedlings and stem diameters at the ground level were recorded using rule and Vernier caliper before fertigation and at the end of fertigation (November 2015). Canopy and stem increases were calculated based on their differences between before and after fertigation. Before the conclusion of the experiment, leaf samples were collected for analysis of physiological parameters indicated below. Seedlings were then harvested by cutting shoots from the substrate surface, and roots were recovered by inverting the containers in water, gently agitating the root system and washing the roots free from the substrate. Roots and shoots were placed in paper bags, initially dried at $105^{\circ} \mathrm{C}$ for $30 \mathrm{~min}$, and then dried to a constant mass at $80^{\circ} \mathrm{C}$. Root and shoot dry weights were recorded.

\subsection{Analysis of Physiological Parameters}

Total $\mathrm{N}$ contents in leaves of seedlings were determined using the Kjeldahl method [20]. For analysis of chlorophyll content, enzymatic activity, and content of soluble saccharides and proteins, leaf samples collected from each replication were immediately weighed and frozen in liquid $\mathrm{N}$. Chlorophyll a and $\mathrm{b}(\mathrm{Chl}$ a and $\mathrm{Chl} b$ ) were analyzed using the acetone-ethanol-mixture method [21], soluble saccharides were assayed by anthrone colorimetry [22,23], soluble proteins were tested using the Coomassie brilliant-blue G-250 staining method [24], peroxidase (POD) activity was examined using the guaiacol method [25], superoxide dismutase (SOD) activity was analyzed by the nitroblue-tetrazolium photoreduction method [26], nitrate reductase activity was determined by spectrophotometry [27], and activities of $\mathrm{N}$ assimilation enzymes including nitrate reductase (NR), glutamine synthetase (GS), and glutamate synthase (GOGAT) were assayed using spectrophotometry methods [22,28]. All the analyses had three replicates.

\subsection{Data Analysis}

Plant growth data, dry weights, and physiological parameters mentioned above were subjected to analysis of variance using SPSS 13.0 for Windows (SPSS, Chicago, IL, USA). When significant differences occurred among treatments per parameter, means were separated using Fisher's Protected Least Significant Differences (LSD) at $p<0.05$ level.

\section{Results}

Seedlings fertigated with different ratios of $\mathrm{NO}_{3}{ }^{-}$and $\mathrm{NH}_{4}{ }^{+}$exhibited signficant differences in plant canopy heights, stem diameters as well as dry weights and physiological parameters. 


\subsection{Plant Growth and Dry Weights}

Plant growth results including increase in canopy heights and stem diameters as well as shoot and root dry weights, are presented in Table 2. Nutrient solutions with both $\mathrm{NO}_{3}{ }^{-}$and $\mathrm{NH}_{4}{ }^{+}$enhanced seedling growth. The greatest increase in canopy heights was observed in seedlings fertigated with an equal ratio of $\mathrm{NO}_{3}{ }^{-}$to $\mathrm{NH}_{4}{ }^{+}$, which significantly differed from those supplied with $\mathrm{T} 1, \mathrm{~T} 2$, and T5 solutions. The equal ratio of $\mathrm{NO}_{3}{ }^{-}$to $\mathrm{NH}_{4}{ }^{+}$also resulted in the greatest increase in stem diameter as well as shoot, root, and total dry weight except for root dry weight of seedlings fertigated with T4 solution which was statistically similar to the seedlings fertigated with T3 solution.

Table 2. The growth and biomass accumulation of Camellia oleifera 'Xianglin 27' seedlings fertigated with six nutrient solutions varying in $\mathrm{NO}_{3}{ }^{-}$to $\mathrm{NH}_{4}{ }^{+}$ratios.

\begin{tabular}{cccccc}
\hline Treatment & $\begin{array}{c}\text { Canopy Height } \\
\text { Increase }(\mathbf{c m})\end{array}$ & $\begin{array}{c}\text { Stem Diameter } \\
\text { Increase }(\mathbf{m m})\end{array}$ & $\begin{array}{c}\text { Shoot Dry } \\
\text { Weight } \mathbf{( g )}\end{array}$ & $\begin{array}{c}\text { Root Dry } \\
\text { Weight } \mathbf{( g )}\end{array}$ & $\begin{array}{c}\text { Total Dry } \\
\text { Weight }(\mathbf{g})\end{array}$ \\
\hline T0 (0:0) & $5.20 \pm 0.52 \mathrm{c}$ & $1.43 \pm 0.04 \mathrm{c}$ & $0.83 \pm 0.01 \mathrm{e}$ & $0.68 \pm 0.03 \mathrm{~d}$ & $1.52 \pm 0.03 \mathrm{e}$ \\
$\mathrm{T} 1(1: 0)$ & $7.83 \pm 1.07 \mathrm{~b}$ & $1.67 \pm 0.12 \mathrm{~b}$ & $1.11 \pm 0.06 \mathrm{~d}$ & $0.82 \pm 0.05 \mathrm{c}$ & $1.93 \pm 0.11 \mathrm{~d}$ \\
$\mathrm{~T} 2(7: 3)$ & $9.03 \pm 0.23 \mathrm{ab}$ & $1.86 \pm 0.06 \mathrm{ab}$ & $1.25 \pm 0.06 \mathrm{c}$ & $0.90 \pm 0.06 \mathrm{~b}$ & $2.16 \pm 0.10 \mathrm{c}$ \\
T3 $(1: 1)$ & $10.53 \pm 0.55 \mathrm{a}$ & $2.00 \pm 0.18 \mathrm{a}$ & $1.49 \pm 0.05 \mathrm{a}$ & $1.05 \pm 0.05 \mathrm{a}$ & $2.54 \pm 0.10 \mathrm{a}$ \\
T4 (3:7) & $8.97 \pm 1.72 \mathrm{ab}$ & $1.71 \pm 0.08 \mathrm{~b}$ & $1.35 \pm 0.04 \mathrm{~b}$ & $0.99 \pm 0.01 \mathrm{a}$ & $2.34 \pm 0.05 \mathrm{~b}$ \\
T5 (0:1) & $7.10 \pm 1.22 \mathrm{~b}$ & $1.58 \pm 0.17 \mathrm{bc}$ & $1.17 \pm 0.07 \mathrm{~cd}$ & $0.83 \pm 0.02 \mathrm{c}$ & $2.00 \pm 0.09 \mathrm{~cd}$ \\
\hline
\end{tabular}

Different letters within a column represent significant difference at $p<0.05$ level tested by Fisher's Protected Least Significant Differences (LSD).

\subsection{Leaf Total Nitrogen Content}

Total $\mathrm{N}$ contents of leaves increased from $8.6 \mathrm{~g} \mathrm{~kg}^{-1}$ in seedlings fertigated with a solution devoid of $\mathrm{N}$ (T0) to $13.5 \mathrm{~g} \mathrm{~kg}^{-1}$ in seedlings supplied with an equal ratio of $\mathrm{NO}_{3}{ }^{-}$to $\mathrm{NH}_{4}{ }^{+}$(T3) and then decreased when seedlings were treated with $\mathrm{NO}_{3}{ }^{-}$and $\mathrm{NH}_{4}{ }^{+}$at a ratio of 3:7 (Figure 1). There were no significant differences in total $\mathrm{N}$ content among seedlings fertigated with $\mathrm{T} 0, \mathrm{~T} 1$ or $\mathrm{T} 5$ solutions.

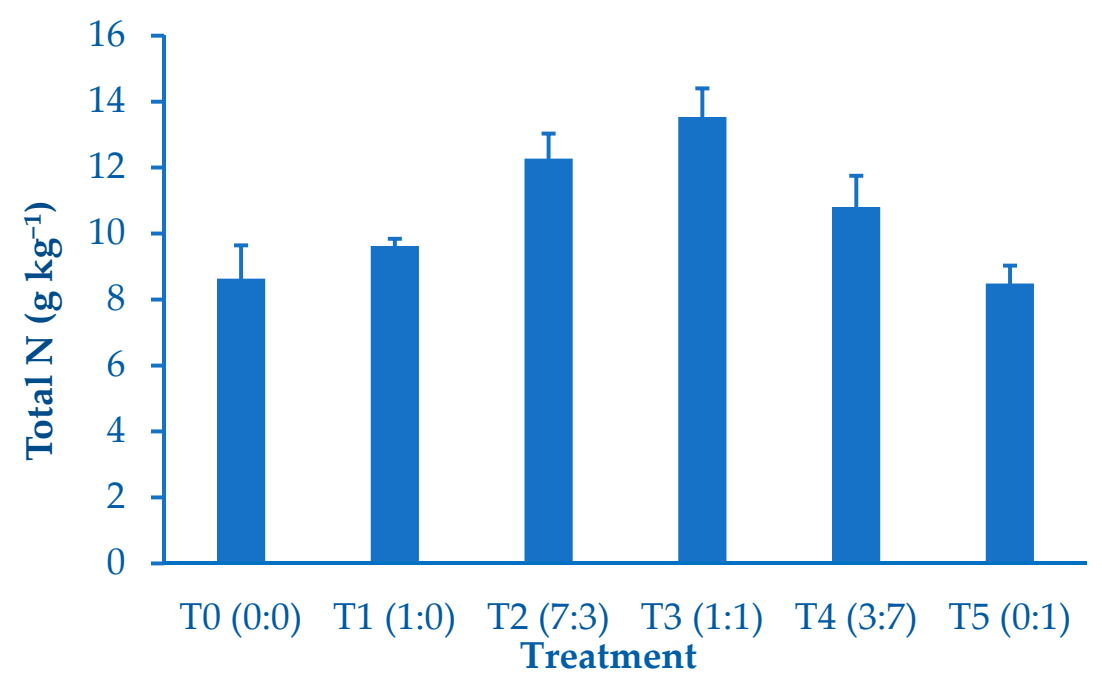

Figure 1. Total nitrogen content in leaves of Camellia oleifera 'Xianglin 27' seedlings fertigated with six nutrient solutions varying in $\mathrm{NO}_{3}{ }^{-}$to $\mathrm{NH}_{4}{ }^{+}$ratios.

\subsection{Chlorophyll Content}

Chlorophyll (Chl) a contents were about three-fold higher than chl b in C. oleifera 'Xianglin 27' leaves regardless of treatments. However, chl a and $\mathrm{b}$ as well as total chl content were significantly affected by fertigation (Table 3). Seedlings fertigated with an equal ratio of $\mathrm{NO}_{3}{ }^{-}$and $\mathrm{NH}_{4}{ }^{+}$had chl a, $\mathrm{b}$, and total chl contents comparable to those fertigated with a solution with a 3:7 ratio of $\mathrm{NO}_{3}{ }^{-}: \mathrm{NH}_{4}{ }^{+}$ 
(T4). Leaves of seedlings supplied with an equal ratio (T3) of $\mathrm{NO}_{3}{ }^{-}$and $\mathrm{NH}_{4}{ }^{+}$had significantly higher chl a and total chl than T0, T1, T2, and T5 and higher chl b than T0, T2, and T5.

Table 3. Leaf chlorophyll content based on fresh weight of Camellia oleifera 'XL27' seedlings fertigated with six nutrient solutions varying in $\mathrm{NO}_{3}{ }^{-}$to $\mathrm{NH}_{4}{ }^{+}$ratios.

\begin{tabular}{|c|c|c|c|}
\hline Treatment & Chl a (mg.g $\left.{ }^{-1} \mathrm{FW}\right)$ & Chl b (mg.g ${ }^{-1}$ FW) & Total chl (mg.g $\left.{ }^{-1} \mathrm{FW}\right)$ \\
\hline T0 (0:0) & $0.95 \pm 0.11 b^{*}$ & $0.31 \pm 0.03 \mathrm{~d}$ & $1.26 \pm 0.14 \mathrm{~b}$ \\
\hline $\mathrm{T} 1(1: 0)$ & $0.99 \pm 0.09 \mathrm{~b}$ & $0.35 \pm 0.02 \mathrm{abc}$ & $1.34 \pm 0.09 b$ \\
\hline T2 (7:3) & $0.97 \pm 0.03 \mathrm{~b}$ & $0.33 \pm 0.02 \mathrm{bcd}$ & $1.30 \pm 0.05 b$ \\
\hline T3 $(1: 1)$ & $1.41 \pm 0.17 \mathrm{a}$ & $0.36 \pm 0.01 \mathrm{a}$ & $1.76 \pm 0.17 \mathrm{a}$ \\
\hline $\mathrm{T} 4(3: 7)$ & $1.08 \pm 0.04 \mathrm{ab}$ & $0.36 \pm 0.01 \mathrm{a}$ & $1.44 \pm 0.05 \mathrm{ab}$ \\
\hline T5 $(0: 1)$ & $0.97 \pm 0.03 \mathrm{~b}$ & $0.32 \pm 0.01 \mathrm{~cd}$ & $1.29 \pm 0.04 \mathrm{~b}$ \\
\hline
\end{tabular}

* The values represent mean chlorophyll (chl). Different letters within a column represent significant differences at a level of $p<0.05$ tested using Fisher's LSD.

\subsection{Peroxidase (POD) and Superoxide Dismutase (SOD) Activities}

Seedlings fertigated with an equal ratio of $\mathrm{NO}_{3}{ }^{-}$and $\mathrm{NH}_{4}{ }^{+}$exhibited the highest activities of both SOD and POD (Table 4). But the SOD activity in T3-treated leaves was not statistically different from the other treatments except for that of $\mathrm{T} 0$ that was much lower than that of $\mathrm{T} 3$ treatment. The POD activities in leaves of seedlings receiving T2 and T3 solutions were similar, but POD activity in leaves of seedlings supplied with T3 was significantly greater than the other treatments.

Table 4. Peroxidase (POD) and Superoxide Dismutase (SOD) activities in leaves of Camellia oleifera 'Xianglin 27' seedlings fertigated with six nutrient solutions varying in $\mathrm{NO}_{3}{ }^{-}$to $\mathrm{NH}_{4}{ }^{+}$ratios.

\begin{tabular}{ccc}
\hline Treatment & SOD $\left(\mathbf{U} \cdot \mathbf{g}^{-\mathbf{1}} \mathbf{F W}\right)$ & POD $\left(\mathbf{U} \cdot \mathbf{g}^{\mathbf{- 1}} \mathbf{F W} \cdot \mathbf{m i n}^{\mathbf{- 1}}\right)$ \\
\hline T0 $(0: 0)$ & $314.64 \pm 14.37 \mathrm{~b}$ & $754.29 \pm 248.79 \mathrm{~b}$ \\
T1 $(1: 0)$ & $334.09 \pm 12.02 \mathrm{ab}$ & $950.04 \pm 252.69 \mathrm{~b}$ \\
T2 $(7: 3)$ & $356.66 \pm 6.54 \mathrm{ab}$ & $1195.94 \pm 385.13 \mathrm{ab}$ \\
T3 $(1: 1)$ & $367.01 \pm 15.63 \mathrm{a}$ & $1579.03 \pm 341.98 \mathrm{a}$ \\
T4 $(3: 7)$ & $359.07 \pm 0.80 \mathrm{ab}$ & $982.99 \pm 108.93 \mathrm{~b}$ \\
T5 $(0: 1)$ & $334.50 \pm 28.31 \mathrm{ab}$ & $814.91 \pm 224.00 \mathrm{~b}$ \\
\hline
\end{tabular}

Different letters within a column represent significant differences at a level of $p<0.05$ tested using Fisher's LSD.

\subsection{Nitrate Reductase (NR), Glutamine Synthetase (GS), and Glutamate Synthase (GOGAT) Activities}

The application of T3 nutrient solution resulted in the highest activity of NR although it was not significantly different from T1 and T2 treatments; it did differ significantly from T4 and T5 (Table 5). The highest activity of GS was detected in leaves of seedlings fertigated with $\mathrm{T} 2\left(\mathrm{NO}_{3}{ }^{-}\right.$to $\mathrm{NH}_{4}{ }^{+}$at a ratio of 7:3), followed by those treated with $\mathrm{T} 3$ and T4 solutions. Activities of GS in seedlings fertigated with the remaining solutions were much lower than the mentioned solutions. In general, increasing the ratio of $\mathrm{NH}_{4}{ }^{+}$caused increased activities of GOGAT in seedling leaves. Seedlings fertigated without $\mathrm{NH}_{4}{ }^{+}$had significantly lower activities of GOGAT than those fertigated with $\mathrm{NH}_{4}{ }^{+}$.

Table 5. Nitrate Reductase (NR), Glutamine Synthetase (GS), and Glutamate Synthase (GOGAT) activities in leaves of Camellia oleifera 'Xianglin 27' seedlings fertigated with six nutrient solutions varying in $\mathrm{NO}_{3}{ }^{-}$to $\mathrm{NH}_{4}{ }^{+}$ratios.

\begin{tabular}{|c|c|c|c|}
\hline Treatment & $\mathrm{NR}\left(\mu \mathrm{g} \mathrm{NO}_{3}^{-} \mathrm{g}^{-1} \mathrm{FW} \mathrm{h}^{-1}\right)$ & $\mathrm{GS}\left(\mu \mathrm{mol} \cdot \mathrm{g}^{-1} \mathrm{FW} \mathrm{h}^{-1}\right)$ & GOGAT $\left(\mu \mathrm{mol} \cdot \mathrm{g}^{-1} \mathrm{FW} \mathrm{h}^{-1}\right)$ \\
\hline T0 $(0: 0)$ & $29.43 \pm 1.75 c$ & $32.97 \pm 0.75 \mathrm{~d}$ & $13.80 \pm 0.64 \mathrm{~d}$ \\
\hline $\mathrm{T} 1(1: 0)$ & $36.12 \pm 4.49 \mathrm{ab}$ & $44.77 \pm 2.88 c$ & $17.60 \pm 1.24 \mathrm{c}$ \\
\hline $\mathrm{T} 2(7: 3)$ & $39.06 \pm 1.67 \mathrm{ab}$ & $61.84 \pm 2.98 \mathrm{a}$ & $21.26 \pm 2.23 b$ \\
\hline T3 $(1: 1)$ & $42.51 \pm 4.95 \mathrm{a}$ & $57.65 \pm 2.28 \mathrm{~b}$ & $25.48 \pm 1.10 \mathrm{a}$ \\
\hline $\mathrm{T} 4(3: 7)$ & $32.98 \pm 4.82 \mathrm{bc}$ & $54.43 \pm 0.68 \mathrm{~b}$ & $26.65 \pm 1.11 \mathrm{a}$ \\
\hline $\mathrm{T} 5(0: 1)$ & $29.05 \pm 2.53 c$ & $48.02 \pm 1.31 \mathrm{c}$ & $25.50 \pm 0.75 a$ \\
\hline
\end{tabular}

Different letters within a column represent significant differences at a level of $p<0.05$ tested using Fisher's LSD. 


\subsection{Contents of Soluble Saccharides and Soluble Proteins}

Soluble saccharide and protein contents generally increased with the increased ratios of $\mathrm{NH}_{4}{ }^{+}$, and then decreased when $\mathrm{NH}_{4}{ }^{+}$supply was above $50 \%$ (Table 6). The highest soluble saccharides occurred in leaves of seedlings fertigated with an equal ratio of $\mathrm{NO}_{3}{ }^{-}$and $\mathrm{NH}_{4}{ }^{+}$. The highest soluble proteins occurred in leaves of seedlings fertigated with either T3 or T4 nutrient solutions, which were significantly different from those of the other treatments.

Table 6. Soluble saccharide and protein contents in leaves of Camellia oleifera 'Xianglin 27' seedlings fertigated with six nutrient solutions varying in $\mathrm{NO}_{3}{ }^{-}$to $\mathrm{NH}_{4}{ }^{+}$ratios.

\begin{tabular}{ccc}
\hline Treatment & Saccharides $(\% \mathbf{F W})$ & Soluble Proteins $\left(\mathbf{m g} \cdot \mathbf{g}^{-\mathbf{1}} \mathbf{F W}\right)$ \\
\hline T0 (0:0) & $3.92 \pm 0.33 \mathrm{c}$ & $7.34 \pm 0.81 \mathrm{~d}$ \\
T1 (1:0) & $4.62 \pm 0.30 \mathrm{~b}$ & $9.99 \pm 0.65 \mathrm{c}$ \\
T2 (7:3) & $4.96 \pm 0.43 \mathrm{~b}$ & $11.57 \pm 0.90 \mathrm{~b}$ \\
T3 (1:1) & $5.68 \pm 0.32 \mathrm{a}$ & $14.27 \pm 0.32 \mathrm{a}$ \\
T4 (3:7) & $5.05 \pm 0.26 \mathrm{~b}$ & $13.72 \pm 0.83 \mathrm{a}$ \\
T5 (0:1) & $4.65 \pm 0.24 \mathrm{~b}$ & $11.18 \pm 0.54 \mathrm{bc}$
\end{tabular}

Different letters within a column represent significant differences at a level of $p<0.05$ tested using Fisher's LSD.

\section{Discussion}

Camellia oleifera is one of four major woody oil plants in the world. Its production has significantly increased over the last 20 years in China and is expected to expand from 3.67 million ha to 4.67 million ha by 2020 [29]. The increased production requires science-based information on nutrient management. $\mathrm{N}$ is an essential nutrient for plant growth, and large quantities of $\mathrm{N}$ fertilizers are applied to ensure high crop productivity [30]. Commercial $\mathrm{N}$ fertilizers are comprised of $\mathrm{NO}_{3}{ }^{-}, \mathrm{NH}_{4}{ }^{+}$or $\mathrm{CO}\left(\mathrm{NH}_{2}\right)_{2}$. $\mathrm{N}$ form or the ratios of $\mathrm{NO}_{3}{ }^{-}$and $\mathrm{NH}_{4}{ }^{+}$can significantly affect plant growth and development [31]. How different ratios of $\mathrm{NO}_{3}{ }^{-}$and $\mathrm{NH}_{4}{ }^{+}$could affect $C$. oleifera growth has not been investigated thus far. The present work studied the effects of different ratios of $\mathrm{NO}_{3}{ }^{-}$and $\mathrm{NH}_{4}{ }^{+}$on seedling growth of a C. oleifera cultivar Xianglin 27. Results showed that canopy height and stem diameter increased, and shoot and root dry weights were the highest for the seedlings fertigated with the solution containing an equal ratio of $\mathrm{NO}_{3}{ }^{-}$and $\mathrm{NH}_{4}{ }^{+}$. The increased plant biomass was accompanied with enhanced uptake of N, higher chlorophyll content, increased activity of SOD, POD, NR, GS, and GOGAT as well as the highest concentration of saccharides and soluble proteins in leaf tissue studied.

Our results differ from the conventional thought that plants adapted to acidic soils prefer $\mathrm{NH}_{4}{ }^{+}-\mathrm{N}$. This is based on the fact that $\mathrm{NH}_{4}{ }^{+}$has a positive charge, and when roots take up $\mathrm{NH}_{4}{ }^{+}$, an identically charged molecule, in this case $\mathrm{H}^{+}$, is released from roots to maintain a balanced $\mathrm{pH}$ inside the plant cells. The release of $\mathrm{H}^{+}$keeps the rhizosphere $\mathrm{pH}$ at acidic levels, thus maintaining a suitable $\mathrm{pH}$ environment for root growth. Another reason is that $\mathrm{NH}_{4}{ }^{+}$is generally a major form of $\mathrm{N}$ in acidic soils. In a study of $\mathrm{N}$ forms and root-zone $\mathrm{pH}$ on growth and $\mathrm{N}$ uptake of tea (Camellia sinensis (L.) O. Kuntze) plants, a close relative of C. oleiferea that is also tolerant to acidic soils, Ruan et al. [32] reported that plants fertilized with $\mathrm{NO}_{3}{ }^{-}$exhibited yellowish leaves and reduced growth compared to those receiving $\mathrm{NH}_{4}{ }^{+}$or $\mathrm{NO}_{3}{ }^{-}$and $\mathrm{NH}_{4}{ }^{+}$regardless of root-zone $\mathrm{pH}$. Absorption of $\mathrm{NO}_{3}{ }^{-}$was 2 to 3.4 fold slower than $\mathrm{NH}_{4}{ }^{+}$when supplied separately, and 6 to 16 fold slower when supplied simultaneously. Additionally, supply of $\mathrm{NO}_{3}{ }^{-}$reduced chlorophyll content and GS activity [32]. Coffee plants (Coffea arabica L.) fed with $\mathrm{NH}_{4}{ }^{+}$also absorbed and assimilated more $\mathrm{N}$ than plants fed with $\mathrm{NH}_{4}{ }^{+}$and $\mathrm{NO}_{3}{ }^{-}$or $\mathrm{NO}_{3}{ }^{-}$only [33]. Our study did not examine the specific absorption rate of $\mathrm{NO}_{3}{ }^{-}$and $\mathrm{NH}_{4}{ }^{+}$but showed that seedling growth of $C$. oleiferea was the greatest when $\mathrm{NO}_{3}{ }^{-}$and $\mathrm{NH}_{4}{ }^{+}$were applied at the 1:1 ratio, and $\mathrm{NO}_{3}{ }^{-}$and $\mathrm{NH}_{4}{ }^{+}$applied separately had much lower dry weight accumulation and lower contents of total $\mathrm{N}$, chlorophyll, soluble saccharides and proteins as well as lower enzymatic activities of POD, SOD, NR, GS, and GOGAT. Our results agreed with those for $C$. sinensis that application of both $\mathrm{NH}_{4}{ }^{+}$and $\mathrm{NO}_{3}{ }^{-}$increased $\mathrm{N}$ uptake and increased biomass 
accumulation [32] but differed from those that held that application of $\mathrm{NH}_{4}{ }^{+}$alone was equal or better than the application of $\mathrm{NH}_{4}{ }^{+}$or $\mathrm{NO}_{3}{ }^{-}$.

Recently, increasing evidence has suggested that mixtures of $\mathrm{NO}_{3}{ }^{-}$and $\mathrm{NH}_{4}{ }^{+}$are beneficial for plant growth compared to $\mathrm{NO}_{3}{ }^{-}$or $\mathrm{NH}_{4}{ }^{+}$alone [31], a finding which may be attributed to several factors: (1) Nitrate is a nutrient, and plants have developed a whole set of systems for uptake, transport, and assimilation of $\mathrm{NO}_{3}{ }^{-}$. (2) There is a complementary effect between $\mathrm{NO}_{3}{ }^{-}$and $\mathrm{NH}_{4}{ }^{+}$as reported by Lima et al. [34]. Application of $\mathrm{NH}_{4}{ }^{+}$stimulates lateral root branching, whereas $\mathrm{NO}_{3}{ }^{-}$stimulates lateral root elongation. When $\mathrm{NO}_{3}{ }^{-}$and $\mathrm{NH}_{4}{ }^{+}$are applied together, concomitant enhancement of branching and elongation of lateral roots occurs, suggesting that the application of $\mathrm{NO}_{3}{ }^{-}$and $\mathrm{NH}_{4}{ }^{+}$has local, complementary effects on root growth [31]. (3) The presence of $\mathrm{NO}_{3}{ }^{-}$enhances $\mathrm{NH}_{4}{ }^{+}$uptake and decreases $\mathrm{NH}_{4}{ }^{+}$efflux. A study with rice (Oryza sativa L.) showed that an increased total $\mathrm{NH}_{4}{ }^{+}$uptake occurred concomitantly with a decrease in total $\mathrm{NH}_{4}{ }^{+}$efflux in the presence of $\mathrm{NO}_{3}{ }^{-}$, thus enhancing net $\mathrm{NH}_{4}{ }^{+}$uptake [35]. (4) Nitrate is a local and systemic signal molecule. A wide range of genes can be regulated by $\mathrm{NO}_{3}{ }^{-}$, which significantly affect plant growth and development [36]. Although the present study did not investigate $\mathrm{N}$ effects at molecular levels, our results suggest that the increased uptake of $\mathrm{N}$ in seedlings fertigated with an equal ratio of $\mathrm{NO}_{3}{ }^{-}$and $\mathrm{NH}_{4}{ }^{+}$could enhance $\mathrm{NR}$ and GS/GOGAT cycle, increase chlorophyll content and Rubisco activity and thus raise soluble saccharides and proteins, and subsequently plant growth, i.e., dry matter accumulation. Additionally, SOD and POD can scavenge reactive oxygen species (ROS), protect cell membrane structure, and maintain the ROS metabolism balance in plants. The increased activities of SOD and POD may safeguard plants from ROS damage. (5) Root-associated microbes could be another factor influencing $N$ uptake, such as mycorrhizal fungi [37]. Roots of Rhododendron fortunei Lindl., also an acid-loving plant, can effectively use $\mathrm{NO}_{3}{ }^{-}$due to the presence of ericoid mycorrhizal fungus (Oidiodendron maius) that can fully utilize $\mathrm{NO}_{3}{ }^{-}$[38,39]. It is unknown if $C$. sinensis and C. oleiferea have different rhizosphere mycorrhizal fungi or other microbes. Nevertheless, further research to test the aforementioned possibilities is needed, and information gathered from such tests will improve current nutrient management programs for C. oleifera production.

\section{Conclusions}

Camellia oleifera is a traditional woody oil plant in China and has been cultivated for more than 2000 years. Recent recognition of its healthy value as a cooking oil and its adaptation to a wide range of subtropical forest soils has renewed interest in its cultivation. As C. oleifera is an acid-loving plant, farmers have been using chemical fertilizers with $\mathrm{NH}_{4}{ }^{+}$or urea as main sources of $\mathrm{N}$ to produce this crop. As a result, production of C. oleifera based on farmers' experience has not resulted in significant improvement in crop yield. Thus, there is an urgent need for science-based information on nutrient management. This study determined how different ratios of $\mathrm{NO}_{3}{ }^{-}$and $\mathrm{NH}_{4}{ }^{+}$could affect growth of C. oleifera seedlings. Results show that $C$. oleifera seedlings prefer both $\mathrm{NO}_{3}{ }^{-}$and $\mathrm{NH}_{4}{ }^{+}$with a ratio of 1:1. Seedlings receiving $\mathrm{NO}_{3}{ }^{-}$and $\mathrm{NH}_{4}{ }^{+}$at this ratio had highest total $\mathrm{N}$ content and dry weight accumulation; elevated chrolophyll, soluble saccharide and protein contents as well as higher activities of POD, SOD, NR, GS, and GOGAT. Our results show that growth of $C$. oleifera seedlings is enhanced using fertilizers with an equal ratio of $\mathrm{NO}_{3}{ }^{-}$and $\mathrm{NH}_{4}{ }^{+}$. Further study on evaluating mature plant's responses to different ratios of $\mathrm{NO}_{3}{ }^{-}$and $\mathrm{NH}_{4}{ }^{+}$will be conducted to determine if they also require such a ratio of $\mathrm{NO}_{3}{ }^{-}$and $\mathrm{NH}_{4}{ }^{+}$.

Author Contributions: Designed the experiment: Y.C., R.W., L.C., Performed the experiments and collected the data. R.W., Z.Z., X.W. (Xiangnan Wang), Y.P., S.P., A.L. Contributed to writing the manuscript: R.W., J.C., Y.C., X.W. (Xiangying Wei).

Funding: This research was funded by the Hunan Natural Science Foundation (2017JJ2145).

Acknowledgments: The authors thank Terri Mellich for reviewing this manuscript.

Conflicts of Interest: The authors declare no conflict of interest. 


\section{References}

1. Chen, Y.; Wang, B.; Chen, J.; Wang, X.; Wang, R.; Peng, S.; Chen, L.; Ma, L.; Luo, J. Identification of Rubisco $r b c L$ and $r b c S$ in Camellia oleifera and their potential as molecular markers for selection of high tea oil cultivars. Front. Plant Sci. 2015, 6, 189. [CrossRef] [PubMed]

2. Ma, J.; Ye, H.; Rui, Y.; Chen, G.; Zhang, N. Fatty acid composition of Camellia oleifera oil. J. für Verbraucherschutz und Lebensmittelsicherheit 2011, 6, 9-12. [CrossRef]

3. Dong, B.; Wu, B.; Hong, W.; Li, X.; Li, Z.; Xue, L.; Huang, Y. Transcriptome analysis of the tea oil camellia (Camellia oleifera) reveals candidate drought stress genes. PLoS ONE 2017, 12, e0181835. [CrossRef]

4. Cheng, Y.; Wu, S.; Ho, C.; Huang, S.; Cheng, C.; Yen, G. Beneficial effects of camellia oil (Camellia oleifera Abel.) on ketoprofen-induced gastrointestinal mucosal damage through upregulation of HO- 1 and VEGF. J. Agric. Food Chem. 2014, 62, 642-650. [CrossRef] [PubMed]

5. Wang, B.; Chen, J.; Chen, L.; Wang, X.; Wang, R.; Ma, L.; Peng, S.; Luo, J.; Chen, Y. Combined drought and heat stress in Camellia oleifera cultivars: Leaf characteristics, soluble sugar and protein contents, and Rubisco gene expression. Trees 2015, 29, 1483-1492. [CrossRef]

6. Kong, W.; Liu, X.; Yao, X.; Wang, K.; Ren, H.; Cao, Y. Research on photosynthetic characteristics of four oil-tea (Camellia) species. J. Southwest Univ. (Natl. Sci. Ed.) 2013, 35, 1-7.

7. Liu, C.; Chen, L.; Tang, W.; Peng, S.; Li, M.; Deng, N.; Chen, Y. Predicting potential distribution and evaluating suitable soil condition of oil tea camellia in China. Forests 2018, 9, 487. [CrossRef]

8. Song, X.; Tang, J.; Qin, Q.; Pan, B.; Cao, J. Mechanism of biomass accumulation and nutrient distribution in Camellia oleifera mature forest. J. South. Agric. 2014, 45, 255-258.

9. Marschner, P. Rhizosphere Biology. In Marschner's Mineral Nutrition of Higher Plants, 3rd ed.; Academic Press: New York, NY, USA, 2012.

10. Weber, K.; Burow, M. Nitrogen-Essential macronutrient and signal controlling flowering time. Physiol. Plant. 2018, 162, 251-260. [CrossRef] [PubMed]

11. Zhao, X.; Bi, G.; Harkess, R.L.; Blythe, E.K. Effects of Different $\mathrm{NH}_{4}: \mathrm{NO}_{3}$ ratios on growth and nutrition uptake in Iris germanica 'Immortality'. HortScience 2016, 51, 1045-1049.

12. Bauer, G.; Berntson, G. Ammonium and nitrate acquisition by plants in response to elevated $\mathrm{CO}_{2}$ concentration: The roles of root physiology and architecture. Tree Physiol. 2001, 21, 137-144. [CrossRef] [PubMed]

13. Tam, N.; Wong, Y. Effect of ammonia concentrations on growth of Chlorella vulgaris and nitrogen removal from media. Bioresour. Technol. 1996, 57, 45-50. [CrossRef]

14. Lu, Y.L.; Xu, Y.C.; Shen, Q.R.; Dong, C.X. Effects of different nitrogen forms on the growth and cytokinin content in xylem sap of tomato (Lycopersicon esculentum Mill.) seedlings. Plant Soil 2009, 315, 67. [CrossRef]

15. Sun, M.; Lu, X.; Cao, X. Effect of different forms of nitrogen on the activity of nitrate reductase and expression of the relative genes in Citrus sinensis $\times$ Poncirus trifoliate. J. Fruit Sci. 2017, 34, 410-417.

16. Robinson, N.; Brackin, R.; Vinall, K.; Soper, F.; Holst, J.; Gamage, H.; Paungfoo-Lonhienne, C.; Rennenberg, H.; Lakshmanan, P.; Schmidt, S. Nitrate paradigm does not hold up for sugarcane. PLoS ONE 2011, 6, e19045. [CrossRef]

17. Chen, Y.; Peng, S.; Wang, X.; Yang, X.; He, J.; Wand, D. Study of high yield cultivation technologies of oil-tea camellia (Camellia oleifera)-formulate fertilization. For. Res.-Chin. Acad. For. 2007, 20, 650.

18. Xu, P.; Xie, L. Researches on Fertilization of Camellia Oleifera. Chin. Agric. Sci. Bull. 2011, 8, 1-6.

19. Liu, J.; Wu, L.; Chen, D.; Li, M.; Wei, C. Soil quality assessment of different Camellia oleifera stands in mid-subtropical China. Appl. Soil Ecol. 2017, 113, 29-35. [CrossRef]

20. Parkinson, J.; Allen, S. A wet oxidation procedure suitable for the determination of nitrogen and mineral nutrients in biological material. Commun. Soil Sci. Plant Anal. 1975, 6, 1-11. [CrossRef]

21. Wang, Q.; Chen, J.; Li, Y. Nondestructive and rapid estimation of leaf chlorophyll and nitrogen status of peace lily using a chlorophyll meter. J. Plant nutr. 2004, 27, 557-569. [CrossRef]

22. Wang, X. The Principle and Measuring Technique on Plant Physiology and Biochemistry; Beijing High Education Press: Beijing, China, 2006.

23. Li, H.S. The Principle and Measuring Technique on Plant Physiology and Biochemistry; Beijing High Education Press: Beijing, China, 1999.

24. Bradford, M.M. A rapid and sensitive method for the quantitation of microgram quantities of protein utilizing the principle of protein-dye binding. Anal. Biochem. 1976, 72, 248-254. [CrossRef] 
25. Maehly, A. The assay of catalases and peroxidases. Methods Biochem. Anal. 1954, 357-424. [CrossRef]

26. Giannopolitis, C.N.; Ries, S.K. Superoxide dismutases: I. Occurrence in higher plants. Plant Physiol. 1977, 59, 309-314. [CrossRef]

27. Pike, C.S.; Cohen, W.S.; Monroe, J.D. Nitrate reductase: A model system for the investigation of enzyme induction in eukaryotes. Biochem. Mol. Biol. Ed. 2002, 30, 111-116. [CrossRef]

28. O'neal, D.; Joy, K. Glutamine synthetase of pea leaves. I. Purification, stabilization, and pH optima. Arch. Biochem. Biophys. 1973, 159, 113-122. [CrossRef]

29. Liu, J.; Wu, L.; Chen, D.; Yu, Z.; Wei, C. Development of a soil quality index for Camellia oleifera forestland yield under three different parent materials in Southern China. Soil Tillage Res. 2018, 176, 45-50. [CrossRef]

30. Tegeder, M.; Masclaux-Daubresse, C. Source and sink mechanisms of nitrogen transport and use. New Phytol. 2018, 217, 35-53. [CrossRef]

31. Hachiya, T.; Sakakibara, H. Interactions between nitrate and ammonium in their uptake, allocation, assimilation, and signaling in plants. J. Exp. Bot. 2016, 68, 2501-2512. [CrossRef]

32. Ruan, J.; Gerendás, J.; Härdter, R.; Sattelmacher, B. Effect of nitrogen form and root-zone $\mathrm{pH}$ on growth and nitrogen uptake of tea (Camellia sinensis) plants. Ann. Bot. 2007, 99, 301-310. [CrossRef]

33. Vaast, P.; Zasoski, R.J. Effects of VA-mycorrhizae and nitrogen sources on rhizosphere soil characteristics, growth and nutrient acquisition of coffee seedlings (Coffea arabica L.). Plant Soil 1992, 147, 31-39. [CrossRef]

34. Lima, J.E.; Kojima, S.; Takahashi, H.; von Wirén, N. Ammonium triggers lateral root branching in Arabidopsis in an AMMONIUM TRANSPORTER1; 3-dependent manner. Plant Cell 2010, 22, 3621-3633. [CrossRef]

35. Kronzucker, H.J.; Siddiqi, M.Y.; Glass, A.D.; Kirk, G.J. Nitrate-ammonium synergism in rice. A subcellular flux analysis. Plant Physiol. 1999, 119, 1041-1046. [CrossRef] [PubMed]

36. O’Brien, J.A.; Vega, A.; Bouguyon, E.; Krouk, G.; Gojon, A.; Coruzzi, G.; Gutiérrez, R.A. Nitrate transport, sensing, and responses in plants. Mol. Plant 2016, 9, 837-856. [CrossRef]

37. Singh, S.; Pandey, A.; Kumar, B.; Palni, L.M.S. Enhancement in growth and quality parameters of tea (Camellia sinensis (L.) O. Kuntze) through inoculation with arbuscular mycorrhizal fungi in an acid soil. Biol. Fertil. Soils 2010, 46, 427-433. [CrossRef]

38. Wei, X.; Chen, J.; Zhang, C.; Pan, D. A new Oidiodendron maius strain isolated from Rhododendron fortunei and its effects on nitrogen uptake and plant growth. Front. Microbiol. 2016, 7, 1327. [CrossRef] [PubMed]

39. Wei, X.; Chen, J.; Pan, D.; Zhang, C. Differential gene expression in Rhododendron fortunei roots colonized by an ericoid mycorrhizal fungus and increased nitrogen absorption and plant growth. Front. Plant Sci. 2016, 7, 1594. [CrossRef] [PubMed] 